\title{
The Effect of Colistin Administration as Medicated Feed on Alanine Aminotransferase and Creatinine Level in Broiler Infected with Escherichia coli
}

\author{
Aisah Nurul Fitri ${ }^{1}$ Ida Fitriana ${ }^{2}$, Antasiswa Windraningtyas Rosetyadewi', Anggi Muhtar \\ Pratama $^{2}$, Aria Ika Septiana ${ }^{2}$, Dwi Cahyo Budi Setiawan ${ }^{2}$, and Agustina Dwi Wijayanti²* \\ ${ }^{1}$ Faculty of Veterinary Medicine, Universitas Gadjah Mada, Yogyakarta, Indonesia \\ ${ }^{2}$ Department of Pharmacology, Faculty of Veterinary Medicine, Universitas Gadjah Mada, Yogyakarta, \\ Indonesia
}

\begin{abstract}
Colistin is a decapeptide antibiotic with narrow spectrum activity, mainly used as treatment for Gram negative bacteria. This study aims to scientifically determine the effect of colistin administration as medicated feed on alanine aminotransferase (ALT) and creatinine level in broiler infected with Escherichia coli. KTOP group as positive control, KTON group as negative control, while I, II, and III groups were infected with Escherichia coli 1 x $108 \mathrm{CFU} / \mathrm{ml} 0.1 \mathrm{ml}$ via intratracheal route. Group I, II, and III were given colistin treatment dosage of $0.3 \mathrm{~g} / \mathrm{kg}$ food, $0.6 \mathrm{~g} / \mathrm{kg}$ food, and $1.2 \mathrm{~g} / \mathrm{kg}$ food. Blood samples were taken through brachial veins for ALT and creatinine examination with a Caretium NB-201 semi-auto chemistry analyzer. Data were examined statistically using IBM SPSS Statistics 24 software and graphically using Microsoft Excel 365. Conclusion of the research by statistical analysis with Kruskal-Wallis test obtained ALT test results $\mathrm{P}=0.147$ and creatinine test results $\mathrm{P}=0.815$. Based on the results of this study, the administration of colistin medicated feed did not cause a significant effect on ALT and creatinine level in broiler infected with Escherichia coli, indicating that colistin has low potential toxicity while given as medicated feed.
\end{abstract}

\section{Introduction}

Antibiotics are substance, produced by one microorganism, or of biological origin which at low concentrations can inhibit the growth of, or are lethal to other microorganisms. Antibiotics will express similar pattern of effectiveness, toxicity, and allergic potential side effects within the same structural class. Beta-lactams, Macrolides, Tetracyclines, Quinolones, Aminoglycosides, Sulfonamides, Glycopeptides and Oxazolidinones are some common classes of antibiotics based on chemical or molecular structures ${ }^{[3]}$. The use of Antibiotics Growth Promotor or AGP has been regulated in UU No. 41 Year 2014 about Animal Health and Husbandry stating that animal feed mixed with certain hormones and/or

\footnotetext{
*Corresponding author: tinabdy@ugm.ac.id
} 
feed additive antibiotics are prohibited ${ }^{[16]}$. Regarding to Technical Guidelines for the Use of Veterinary Drugs in Animal Feed for Therapeutic Purposes in Decree of Directorate General of Animal Health and Husbandry No. 09111/KPTS/PK.350/F/09/2018, antibiotics can be mixed in animal feed and may only be used for therapeutic purposes either through feed or drinking water in right theurapeutic dose and maximum 7 days duration of use ${ }^{[6]}$.

Colistin or often known as colistin sulfate or polymyxin E, one of the antibiotics listed in Critically Important Antimicrobials for Human Medicine, is a narrow spectrum antibiotic and is effective against Gram negative bacteria ${ }^{[18]}$. It is categorized as the last drug choice for the treatment of infectious diseases caused by multiresistant Gram-negative bacteria such as Acinetobacter species, Pseudomonas aeruginosa, and Enterobacteriaceae with multiresistancy to carbapenemase ${ }^{[9]}$. The mechanism of colistin, apart from being bactericidal, is lipopolysaccharides and phospholipids binding to the outer membrane of bacterial cell. It is also able for calcium and magnesium ions binding to neutralize lipopolysaccharides (LPS) ${ }^{[15]}$. Studies of colistin pharmacokinetics in poultry are very limited despite their frequent use for decades although colistin has been extensively used in veterinary medicine for prophylaxis, metaphylaxis, treatment of bacterial infections and growth promotors ${ }^{[2]}$.

Escherichia coli (E. coli) is a Gram-negative, rod shaped, facultative anaerobic bacterium that belongs to the Enterobacteriaceae family ${ }^{[1]}$. Basically, this disease is not a new one, yet it has been attracting concern in veterinary field due to the occurrence of more frequent cases of pathogenic E. coli in poultry industry. Numerous studies show antibiotics resistance to tetracycline, nalidixic acid, ampicillin, amoxicillin, streptomycin, trimethoprim, and cotrimoxazole appeared to be the most common among the E. coli isolates circulating in poultry farms ${ }^{[8]}$. The aim of this study was to determine the effect of colistin as medicated feed on Alanine Transaminase (ALT) and creatinine level in broiler infected with E. coli. Changes in ALT and creatinine profiles were measured after oral administration of colistin medicated feed for 5 days duration in broiler infected with $E$. coli.

\section{Material and Methods}

\subsection{Animal models}

Approval by the Ethical Clearance Commission of Faculty Veterinary Medicine Universitas Gadjah Mada No. 0027/EC-FKH/Int./2018 and protocol of PT. NovindoAgritech Hutama, forty broiler chickens strain Cobb CP 707 bought from PT. Charoen Pokphand Jaya Farm were included in this study. The broilers were housedin UP2KH animal facilities from Day Old Chick (DOC) to 30-day old broilers. KTOP group as positive control, KTON group as negative control, while I, II, III groups were infected with E. coli $1 \times 10^{8} \mathrm{CFU} / \mathrm{ml} 0.1 \mathrm{ml}$ via intratracheal route. Group I, II, III were given colistin treatment dosage of $0.3 \mathrm{~g} / \mathrm{kg}$ food, $0.6 \mathrm{~g} / \mathrm{kg}$ food, $1.2 \mathrm{~g} / \mathrm{kg}$ food. All broilers were judged based on results of serum biochemical analysis prior to study. Blood samples were taken through brachial veins for ALT and creatinine examination with a Caretium NB-201 semi-auto chemistry analyzer.

\subsection{Study design}

The broilers were housed in UP2KH animal facilities from Day Old Chick (DOC) to 30day old broiler. When broilers arrived, the first adaptation was carriedout in a $3 \times 1.5 \mathrm{~m}$ cage with rice husks litters to absorb the smell of Ammonia. During adaptation, broilers were fed with commercial feed Japfa Comfeed BR I Crumble (BR1) and 7 litres of drinking water/day (ratio 15 litres of water : $500 \mathrm{~g}$ ofmashed brown sugar) that was replaced every 
morning for 3 (three) days. Feeding with Japfa Comfeed BR I Crumble (BR1) was continued during starter period and Japfa Comfeed BR II Crumble (BR2) was given during finisher period. Weighing isdone once a week. On the 3rd day, the Newcastle Disease (ND) and Infectious Bursal Disease (IBD / Gumboro) vaccination was carried out with the live MedivacND-IBD vaccine via eyedrops. On the 13th day, the IBD Vaccination via drinking water was carried out with the Medivac Gumboro A live vaccine, continued with the administration of vitamin B complex at a dose of $5 \mathrm{~g}$ dissolved in 7 litres of drinking water. This vitamin is given until 15th day. On the 17 th day, ND vaccination was carried out via drinking water with the Medivac ND clone 45 live vaccine.

Escherichia coli infection was given on the 17th day by dividing the broilers into 5 groups. Groups I, II, and III each contained 10 broilers were infected with E.coli and were given medicated feed treatment, the KTOP group as a positive controlcontained 4 broilers infected with $E$. coli without medicated feed treatment, and theKTON group as a negative control contained 6 broilers without medicated feed treatment and without being infected with E. coli. Escherichia coli infection to KTOP, I, II, and III groups was carried out by injection of E. coli strain $\mathrm{O} 78$ as muchas $0.1 \mathrm{ml} /$ broiler with total colony count of $1 \times 10^{8}$ $\mathrm{CFU} / \mathrm{ml}$ via intratracheal. On day 20 to day 24 groups I, II, and III were each treated with colistin at $0.3 \mathrm{~g} / \mathrm{kg}$ of feed, $0.6 \mathrm{~g} / \mathrm{kg}$ of feed, and $1.2 \mathrm{~g} / \mathrm{kg}$ of feed, while the KTON and KTOP groups werenot given colistin medicated feed. At 3rd week of maintenance, chickens in KTOP group died one by one before blood samples were taken for data analysis. On the 29th day, blood samples were taken via brachial veins for ALT and creatinine examinations.

\subsection{Serum preparation}

Blood samples were taken via brachial veins and collected in a non-EDTA conical tube for ALT and creatinine examination. Centrifugation at $3000 \mathrm{rpm}$ for 10 minuteswas carried out at the Laboratory of Pharmacology, Faculty of Veterinary Medicine, Universitas Gadjah Mada. After centrifugation process was complete, the serum wasseen on the top layer. Serum was then collected using a micropipette into the eppendorf tube to be stored in $4^{\circ} \mathrm{C}$ temperature until further examination.

\subsection{Serum biochemical analysis}

Serum alanine transaminase (ALT) and creatinine were measured using standard reagent kits (Stanbio ALT/GPT Liqui-UV®, Stanbio Liqui-UV®, Stanbio Direct Creatinine LiquiColor ${ }^{\circledR}$, Stanbio LiquiColor ${ }^{\circledR}$ ) and were examined using semi-autochemistry analyzer Caretium NB-201. Based on the results of the examination, the ALT value appeared on the instrument is expressed in units/litre $(\mathrm{U} / \mathrm{L})$ and the creatinine value is expressed in units of milligrams/decilitre (mg/dL).

\subsection{Statistical analysis}

All results are expressed as mean \pm SEM. Data were compared using Kruskal-Wallistest with IBM SPSS Statistics 24 for measurements to investigate both the differences between treatments compared with control values. Significance was setat $\mathrm{P}<0.05$. Data were illustrated graphically using Microsoft Excel 365.

\section{Results}

The graphic in Fig 1. shows ALT mean values of five treatments analysed using Microsoft 
Excel 365 and IBM SPSS 24. The KTOP group as a positive control could not be compared to the results of the data analysis because all the chicken in KTOP group died before blood sampling for data analysis. Based on the results, group II had the highest ALT mean (33.47 $\pm 8.54 \mathrm{U} / \mathrm{L})$ and the KTON group as a negative control had the lowest mean $(9.53 \pm 0.86$ $\mathrm{U} / \mathrm{L})$. The results of group I, II, and III had means and standard deviations of $24.87 \pm 15.08$ $\mathrm{U} / \mathrm{L}, 33.47 \pm 8.54 \mathrm{U} / \mathrm{L}, 23.23 \pm 0.15 \mathrm{U} / \mathrm{L}$. Group II had the highest ALT mean compared to the control group and other treatment groups. Normal ALT concentrations in chicken blood are 9.50-37.2 U/L ${ }^{[11]}$. From the results of the data analysis showed that all groups are still in the normal range.

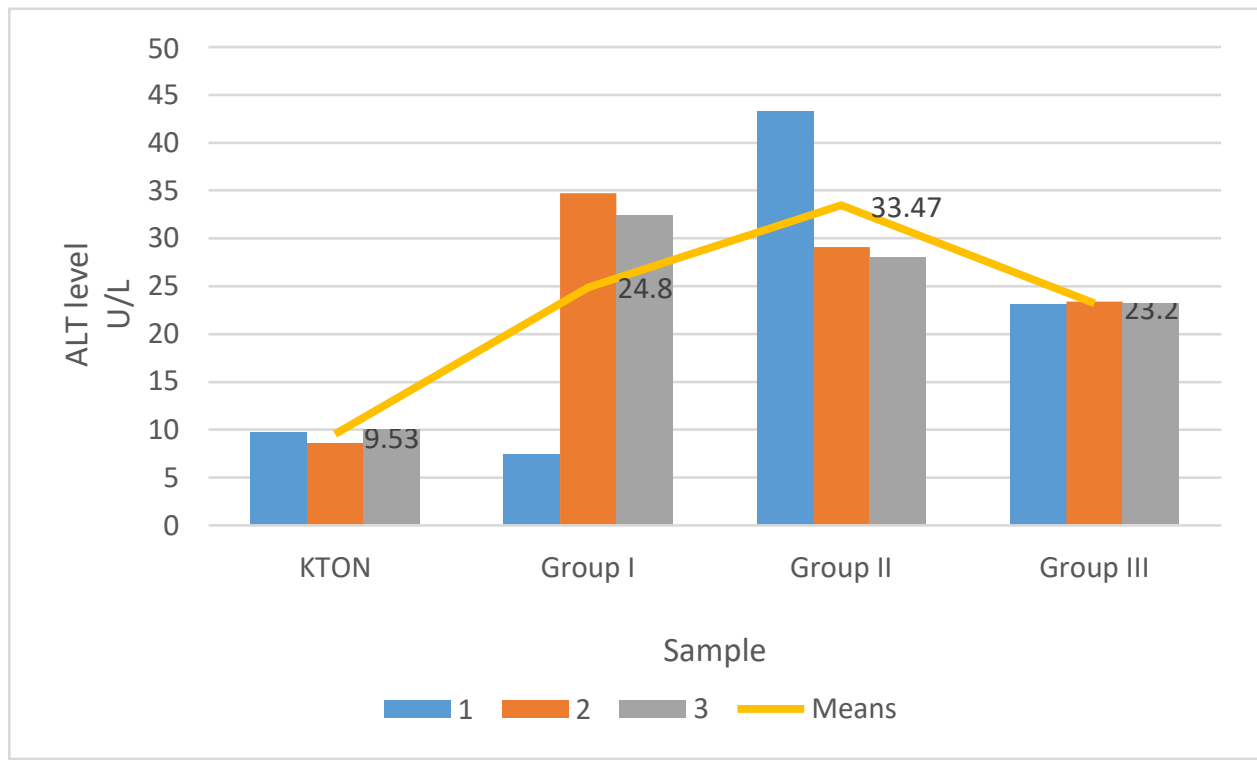

Fig. 1. Comparison of ALT level and ALT means between treatments. KTON = Not given colistin medicated feed treatment and not infected with E. coli. Group I = given colistin medicated feed atdose $0.3 \mathrm{~g} / \mathrm{kg}$ feed. Group II = given colistin medicated feed at dose $0.6 \mathrm{~g} / \mathrm{kg}$ feed. Group III = given colistin medicated feed at dose $1.2 \mathrm{~g} / \mathrm{kg}$ feed.

The graphic in Fig 2. shows creatinine mean values of five treatments analyzed using Microsoft Excel 365 and IBM SPSS 24. The KTOP group as a positive control could not be compared to the results of the data analysis for the same reason shown in Fig. 1. Based on the results of examination and data analysis, KTON group has $0.33 \pm 0.058 \mathrm{mg} / \mathrm{dL}$ mean value, group I has $0.3 \mathrm{mg} / \mathrm{dL}$ mean value, group II has $0.30 \pm 0.10 \mathrm{mg} / \mathrm{dL}$ mean value, and group III has $0.33 \pm 0.058 \mathrm{mg} / \mathrm{dL}$ mean value. The KTON group and group III had the same mean value $(0.33 \pm 0.058 \mathrm{mg} / \mathrm{dL})$, while group I and group II also had the same mean value $(0.30 \mathrm{mg} / \mathrm{dL})$. Normal creatinine levels in chicken are $0.10-0.40 \mathrm{mg} / \mathrm{dL}^{[5]}$. From the results of data analysis, it showed that the creatinine levels of each group I, II, and III treated with colistin medicated feed were still classified as normal. 


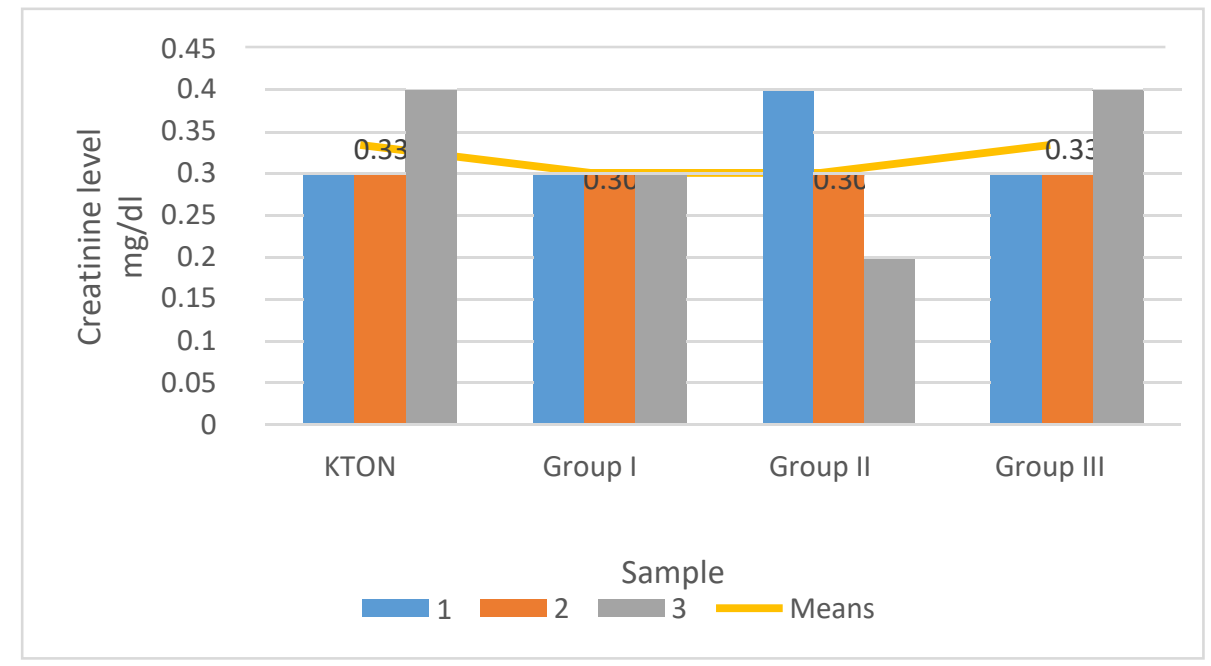

Fig. 2. Comparison of creatinine level and creatinine means between treatments. KTON $=$ Not given colistin medicated feed treatment and not infected with E. coli. Group I = given colistin medicated feed at dose $0.3 \mathrm{~g} / \mathrm{kg}$ feed. Group II = given colistin medicated feed at dose $0.6 \mathrm{~g} / \mathrm{kg}$ feed. Group III $=$ given colistin medicated feed at dose $1.2 \mathrm{~g} / \mathrm{kg}$ feed.

\section{Discussion}

The result of ALT means comparison using Kruskal-Wallis test was $\mathrm{P}=0.147(\mathrm{P}>0.05)$, it showed no significant difference of ALT means between groups. Colistin medicated feed at a dose of $0.3 \mathrm{~g} / \mathrm{kg}$ of feed, $0.6 \mathrm{~g} / \mathrm{kg}$ of feed, and $1.2 \mathrm{~g} / \mathrm{kg}$ of feed effect in blood serum broilers infected with $E$. coli has no significant result compared to broilers that were not given medicated feed and were not infected with $E$. coli. It means colistin considered safe and may not be associated with hepatotoxicity in broilers infected with E. coli.

Table 1. Descriptive ALT and creatinine level of each group.

\begin{tabular}{cccc}
\hline Parameter & Group & Mean & Std. Error \\
\hline & KTON & 9.533 & 0.4978 \\
ALT & I & 24.867 & 8.7087 \\
$(\mathrm{U} / \mathrm{L})$ & II & 33.467 & 4.9269 \\
& III & 23.233 & 0.0882 \\
& KTON & 0.33330 & 0.03333 \\
Creatinine & I & 0.30000 & 0.30000 \\
$(\mathrm{mg} / \mathrm{dL})$ & II & 0.30000 & 0.05774 \\
& III & 0.33333 & 0.03333 \\
\hline
\end{tabular}

Descriptively, group II had the highest mean due to one of the samples had ALT levels increased significantly for up to $43 \mathrm{U} / \mathrm{L}$. The body detoxification process is carried out by the liver enzymes such as AST and ALT through oxidation, reduction, hydrolysis, or conjugation of potentially harmful substances and converting them into physiologically inactive substances. The liver is very open to gut microorganisms and microbial products called pathogen-associated molecular patterns (PAMPs) through the portal vein. In a healthy condition, the liver acts as a gatekeeper to prevent things that trigger infection, such as bacteria and endotoxin from entering the circulatory system. Kupffer cells, macrophages present in the liver, efficiently phagocyte pathogens and PAMPs that enter the liver via arterial or portal circulation or translocation (migration of active bacteria or bacterial products 
from the intestinal lumen to normal sterile tissue) has been known to induce and guard against systemic resistance. In animals infected with E. coli, the elimination of $E$. coli is slow, while the release of endotoxin is high so that it influences the hepatic and systemic circulation ${ }^{[4]}$. An increase in ALT can be caused by the direct effect of bacterial toxins, drugs, chemicals on liver cells, especially those that are closed to the central vein. These cells receive the least amount of nutrients from the blood and are sensitive to hepatotoxins. Inflammation products will directly affect the permeability of the liver cell membranes ${ }^{[12]}$.

From the results, it showed that the creatinine levels of each group I, II, and III treated by colistin medicated feed were still classified as normal. The result of creatinine means comparison using Kruskal-Wallis test showed $\mathrm{P}=0.815(\mathrm{P}>0.05)$, which showed there was no significant difference between the creatinine groups. Based on the results of statistical analysis, colistin medicated feed with a dose of $0.3 \mathrm{~g} / \mathrm{kg}$ of feed, $0.6 \mathrm{~g} / \mathrm{kg}$ of feed, and 1.2 $\mathrm{g} / \mathrm{kg}$ of feed in broiler groups infected with $E$. coli did not have a significant effect on creatinine levels. Creatinine is a muscle protein product produced by muscle metabolism which is released from muscles at an almost constant rate and is excreted in the urine at the same rate. Creatinine is a more reliable indicator of renal function than BUN because it is less influenced by other factors such as diet and hydration ${ }^{[17]}$, a level greater than the normal value indicates impaired kidney function. The mechanism action of colistin involves interactions with lipopolysaccharide molecules in the outer membrane of bacteria, which causes displacement of calcium and magnesium ions and destabilizes the outer membrane causing the leakage of cell content and leading to cell senescence ${ }^{[7]}$. The normal dose of colistin administration ranges from $5-80 \mathrm{mg} / \mathrm{kg}$ body weight ${ }^{[13]}$. In this study, the doses used as variables were $0.3 \mathrm{~g} / \mathrm{kg}$ of feed, $0.6 \mathrm{~g} / \mathrm{kg}$ of feed, and $1.2 \mathrm{~g} / \mathrm{kg}$ of feed. There is no further information regarding the toxicity of colistin in poultry via parenteral or enteral route such as medicated feed. Colistin has been used as an antimicrobial agent for broiler maintenance in Belgium ${ }^{[10]}$. No observations of colistin effect in hematobiochemical serum on broilers were found ${ }^{[13]}$. Further information regarding the toxicity of colistin to broiler creatinine parameters was also not found.

\section{Conclusion}

Group II had the highest ALT levels with an average of $33.47 \pm 8.54 \mathrm{U} / \mathrm{L}$. The KTON group and group III had the same creatinine level $(0.33 \pm 0.058 \mathrm{mg} / \mathrm{dL})$, while group I and group II also had the same average creatinine level $(0.30 \mathrm{mg} / \mathrm{dL})$. In the Kruskal- Wallis test (P> 0.05), the results were no significant difference of ALT and creatinine level between treatments and control groups. Based on these results, the administration of colistin did not have a significant effect on the ALT and creatinine levels between colistin medicated feed treatment groups and control group. The summary of this studyis colistin considered safe and may not be associated with hepatotoxicity and nephrotoxicity regardless of the prohibition of colistin use in Indonesia ${ }^{[16]}$ due to the Decree of Directorate General of Animal Health and Husbandry No. 09160/PK.350/F/12/2019, colistin is the last drug of choice for gastrointestinal infections and bacteremia caused by multidrug resistance in humans, which in its widespread usehas the potential to cause bacterial resistance.

The authors would like to thank the Department of Pharmacology, Faculty of VeterinaryMedicine, Universitas Gadjah Mada, Yogyakarta, Indonesia and Faculty of Veterinary Medicine, Universitas Gadjah Mada, Yogyakarta, Indonesia. We would also like to thank all staff and researchers that helped in the research activity. 


\section{References}

1. Ameen-Ur-Rashid, Shah, S. S. S. A., Khan, M. A., Rafiullah, Ali, A., Anwar, M. Isolation of Escherichia coli from Poultry Liver and its Antibiogram Profile. Research Journal for Veterinary Practitioners 5(1): 13. (2017).

2. Apostolakos, I. and Piccirillo, A. A Review on The Current Situation and Challenges of Colistin Resistance in Poultry Production. Avian Pathology Vol. 47, No. 6, 546-558. (2016).

3. Etebu, E., and Arikekpar, I. Antibiotics: Classification and Mechanisms of Action with Emphasis on Molecular Perspectives. Int. J. Appl. Microbiol. Biotechnol. Res. 4: 9010.1 (2016).

4. Hanslin, K., Sjölin, J., Skorup, P., Wilske, F., Frithiof, R. Larsson, A., Castegren, M., Tano, E., Lipcsey, M. (2019). The Impact of The Systemic Inflammatory Response on Hepatic Bacterial Elimination in Experimental Abdominal Sepsis. Intensive Care Medicine Experimental 7:52

5. Hochleithner, M. Chapter 11: Biochemistries. In: Avian Medicine, Principles and Application. Ritchie, B.W., Harrison, G.J., Harrison, L.R. Winger. Publishing. Florida: 223-245. (2013).

6. Keputusan Direktorat Jenderal Peternakan dan Kesehatan Hewan No.09111/KPTS/PK.350/F/09/2018, tentang Petunjuk Teknis Penggunaan Obat Hewan dalam Pakan untuk Tujuan Terapi.

7. Kumar, H., Chen, B., Kuca, K., Nepovimova, E., Kaushal, A., Nagraik, R., Bhatia, S. K., Dhanjal, D. S., Kumar, V., Kumar, A., Upadhyay, N. K., Verma, R., Kumar, D. Understanding of Colistin Usage in Food Animals and Available Detection Techniques: A Review. Animals 10: 1892. (2020).

8. Kuznetsova, M. V., Gizatullina, J. S., Nesterova, L. Y., Erjavec, M. S. Escherichia coli Isolated from Cases of Colibacillosis in Russian Poultry Farms (Perm Krai): Sensitivity to Antibiotics and Bacteriocins. Microorganisms 8: 741. (2020).

9. Palupi, M.F., Maheshwari, H., Darusman. H.S., Sudarnika, Etih, Wibawan, I.W.T. Resistansi Escherichia coli terhadap Kolistin dan Deteksi Gen Mobilized Colistin Resistance-1 pada Ayam Pedaging Akibat Pemberian Kolistin Sulfat. Jurnal Veteriner Vol. 19 No. 2: 196-207. (2018).

10. Persoons D, J Dewulf, A Smet, L Herman, M Heyndrickx, A Martel, B., Catry, P. Butaye, and F Haesebrouck. Antimicrobial use in Belgian Broiler Production. Prev Vet Med, 105: 320-325. (2012).

11. Roa, M. L., Corredor, J.R., Hernández, M.C. Physiological Behavior of Broilers using Diets with Tithonia Diversifolia and Probiotics. Arch. Zootec 69 (268): 406-417. (2020).

12. Salasia, S.I.O and Hariono, B. Patologi Klinik Veteriner. Penerbit Samudra Biru, Yogyakarta. (2014).

13. Saleemi, M. K., Hussan, M. F. U., Khan, M. Z., Khan, A., Abbas, R. Z., Ahmad, A. Hemato-Biochemical Effects of Colistin Administered Intramuscularly in Growing Broiler Birds. Pak Vet J 34(1): 78-81. (2014).

14. Surat Edaran Direktorat Jenderal Peternakan dan Kesehatan Hewan No. 09160/PK.350/F/12/2019 tentang Pelarangan Penggunaan Colistin pada Hewan.

15. Toelle, Novianti Neliyani. Uji Sensitivitas Staphylococcus spp. Terhadap Beberapa Antibiotik Yang Berbeda. Jurnal Kajian Veteriner Vol. 2 No. 2: 151-154. (2014).

16. Undang-Undang No. 41 Tahun 2014 tentang Peternakan dan Kesehatan Hewan. 
17. Washington, I. M., and Hoosier, G. V. Clinical Biochemistry and Hematology in The Laboratory Rabbit, Guinea Pig, Hamster, and Other Rodents. Academic Press. Oxford. (2012).

18. World Health Organization (WHO). Critically Important Antimicrobials for Human Medicine 5th Revision. WHO Advisory Group on Integrated Surveillance of Antimicrobial Resistance (AGISAR), Geneva. (2017). 